\title{
Proapoptosis and Antiapoptosis-Related Molecules During Postnatal Pancreas Development in Control and Nonobese Diabetic Mice: Relationship with Innervation
}

\author{
Sylvie Durant, Sacha Geutskens, Saskia C. A. van Blokland, Josiane Coulaud, \\ Véronique Alves, Jean-Marie Pleau, Marjan Versnel, Hemmo A. Drexhage, and \\ Françoise Homo-Delarche
}

CNRS UMR 8603 INSERM U25, FRE 2444 (SD, SG, JC, VA, J-MP, FH-D), Université Paris V, Hôpital Necker, Paris, France; and Department of Immunology (SG, SCAvB, MV, HAD), Erasmus University, Rotterdam, The Netherlands

\begin{abstract}
SUMMARY: The mouse pancreas, an immature organ at birth, reaches its adult size and morphology after weaning (3 weeks of age). Around this time, apoptotic phenomena and various types of macrophages are normally present. During development, Fas-Fas ligand (FasL) interactions are known to play a role in apoptotic events involved in tissue remodeling and elimination of damaged cells, and macrophages are routinely observed near apoptotic cells. Apoptosis and Fas-FasL interactions are also thought to be involved in the pathogenesis of autoimmune diseases, particularly type 1 diabetes (T1D). Therefore, we used early postnatal mouse pancreata from three control strains (C57BL/6, DBA/2, BALB/c) and from two strains with the nonobese diabetic (NOD)-related genetic background (the spontaneous T1D NOD model and the lymphocyte-deficient NODscid strain) to study apoptotic phenomena together with the molecular and immunohistochemical expression of proapoptosis (Fas, FasL) and antiapoptosis (Bcl-2) proteins. First, although no major difference in the numbers of total pancreatic apoptotic cells was noted among strains, significantly more $\mathrm{FasL}^{+}$expression was detected immunohistochemically in mice with the NOD genetic background than in control pancreata from birth to 1 month of age. Second, $\mathrm{FasL}^{+}, \mathrm{Fas}^{+}$, and $\mathrm{Bcl}-2^{+}$structures seemed to be associated with innervation, regardless of the strain and age. Third, in control and NOD strains, nerves (identified by immunohistochemical labeling of peripherin or neurofilament 200), were often observed in periductular and peri-insular areas. Finally, some peripherin-positive nerves expressed the interferon-inducible protein-10 chemokine, and various types of macrophages were found to be in close proximity. These data highlight an overlooked, innervation-related aspect of normal mouse postnatal pancreas development with possible implications in T1D pathogenesis. (Lab Invest 2003, 83:227-239).
\end{abstract}

A poptosis and Fas-Fas ligand (Fas-FasL) interaction have been suggested to play a role in various autoimmune processes (Sakata et al, 1998; Sharma et al, 2000; Siegel et al, 2000). Several groups used rodent models of type 1 diabetes (T1D) to investigate (1) whether insulin-producing $\beta$ cells of the islets of Langerhans died via apoptosis and what role $\beta$-cell apoptosis may have in T1D (Augstein et al, 1998; Hugues et al, 2002; Kurrer et al, 1997; O'Brien et al, 1997) and (2) whether Fas-FasL interaction was involved in their autoimmune destruction. The latter approach, in several mouse models including nono-

\section{DOI: 10.1097/01.LAB.0000053914.93282.A5}

Received July 31, 2002.

This research was supported by grants from CNRS, Université Paris V, Fondation de France, Alfediam (associated with Lilly Laboratories), INSERM-NWO, BIOMED "Betimmune", 5th PCRD "Monodiab," and the Diabetes Funds Nederlands.

Address reprint requests to: Dr. F. Homo-Delarche, CNRS UMR 8603, INSERM U25, Hôpital Necker, 161, rue de Sèvres, 75015 Paris, France. E-mail:fhomodel@wanadoo.fr bese diabetic (NOD) Ipr/lpr and transgenic mice expressing FasL on $\beta$ cells, seemed to give conflicting results (Benoist and Mathis, 1997; Griffith and Ferguson, 1997; Sabelko-Downes and Russell, 2000; Sakata et al, 1998; Signore et al, 1998).

Physiologically, Fas-FasL interaction plays a role in apoptotic phenomena involved in morphogenesis and remodeling during normal development, the cycle of death and renewal, and elimination of damaged cells (Burek and Oppenheim, 1996; Granville et al, 1998; Haanen and Vermes, 1996; Kerr et al, 1972; Saikumar et al, 1999; Sakata et al, 1998; Vaux and Korsmeyer, 1999). During morphogenesis, macrophages $(M \phi)$ are routinely observed in close relationship with apoptotic cells. This is particularly well documented in the nervous tissue, in which $\mathrm{M} \phi$ contribute to developmental degeneration and regeneration phenomena (Bruck, 1997; Cuadros et al, 1993; Kuhlmann et al, 2001; Lang and Bishop, 1993; Moujahid et al, 1996; Perry and Brown, 1992).

The pancreas, an immature organ at birth, reaches its adult size and morphology after weaning 
(3 weeks of age in rodents) (Dore et al, 1981; Finegood et al, 1995; Homo-Delarche, 2001). In control rats, apoptotic phenomena at the $\beta$-cell level, in exocrine tissue and also in ductules, have been observed during the postnatal period, leading to the suggestion that remodeling phenomena were not specific to islets (Dore et al, 1981; Petrik et al, 1998; Scaglia et al, 1997). During normal rat pancreas development, $\beta$-cell death seems to be followed rapidly by a wave of islet neogenesis around weaning (Finegood et al, 1995).

Regarding T1D, particularly the spontaneous NOD mouse model (Bach, 1994; Homo-Delarche, 1997), it is classically thought that weaning is the period during which the first immune cells, $\mathrm{M} \phi$, and dendritic cells accumulate around pancreatic ducts and islets (Dahlen et al, 1998; Jansen et al, 1994; Rosmalen et al, 2000a, 2000b). However, more recent data showed several abnormalities in the neonatal NOD pancreas, including more $\beta$-cell apoptosis (Trudeau et al, 2000) and more of some types of $\mathrm{M} \phi$ and dendritic cells (Charré et al, 2002). In addition, a constitutive defect in the clearance of apoptotic $\beta$ cells by NOD macrophages has been suggested to contribute to the initiation of autoimmunity (O'Brien et al, 2002). Finally, because of the existence of common molecules expressed on $\beta$ cells and neurons (Homo-Delarche, 1997, 2001), innervation, which has been quite overlooked until now, seems to be a possible actor in the pathogenesis of the disease, in light of its marked presence, especially perinatally, in periductular and peri-islet areas (Honjin, 1956; Legg, 1968; Persson-Sjogren, 2001; Serizawa et al, 1979; Sunami et al, 2001). Pertinently, in this context, autoreactive $\mathrm{T}$ cells, which routinely target classical islet and central nervous system (CNS) antigens, have been found in diabetic patients, their relatives with high diabetic risk, NOD mice, and patients with multiple sclerosis (Winer et al, 2001a, 2001b).

Taken together, these data led us to investigate, in the pancreata of various strains during the early postnatal period, the expression of proapoptotic (Fas, FasL) and antiapoptotic proteins (Bcl-2), using RTPCR and immunohistochemistry, concomitantly with apoptotic phenomena using the TUNEL (terminal transferase-mediated dUTP nick-end labeling) assay. Pancreas innervation and its relationship with $\mathrm{M} \phi$ were also studied, particularly in light of the results obtained with immunolabeling of proapoptosis and antiapoptosis molecules. To carefully evaluate events involved in normal postnatal pancreas development, we used three control strains (C57BL/6, DBA/2, BALB/ c). To gain insight into T1D pathogenesis, we also analyzed NOD and NODscid pancreata. The latter strain, devoid of functional lymphocytes, does not develop diabetes (Prochazka et al, 1992), but shares some of the early pancreatic and endocrine abnormalities, albeit less markedly, with the NOD mouse (Charré et al, 2002; Homo-Delarche, 1997; Pelegri et al, 2001).

\section{Results}

Similar Total Numbers of Pancreatic Apoptotic Cells in NOD and Control Strains During the First Month of Life

Because apoptotic phenomena were not restricted to $\beta$ cells in control rat pancreata (Finegood et al, 1995), we chose to count all pancreatic apoptotic cells $/ \mathrm{mm}^{2}$ of tissue section, regardless of their type. As shown in Figure 1, numbers varied widely at 3 days of age among the various strains investigated: indeed, a significant strain difference was observed, with higher densities of apoptotic cells only in C57BL/6 pancreata, compared with DBA/2, BALB/c NOD, and NODscid pancreata $(p<0.01$ in all cases, post-hoc analyses). An age effect was also found, once again only in the control C57BL/6 strain, which had significantly more apoptotic cells at 3 days than at 2 and 4 weeks of age, and at 1 week than at 4 weeks of age ( $p$ values from 0.04 to 0.003 , post-hoc analyses). Therefore, unrelated to the NOD background, some strain differences in total pancreatic apoptosis can be seen at birth.

\section{Expression of FasL, Fas, and bcl-2 Genes During Postnatal Mouse Pancreas Development}

Given the paucity of data concerning the expression of these proteins during normal postnatal mouse pancreas development, we first analyzed, by RT-PCR, expression of fas $L$, fas, and $b c /-2$ genes in pancreata from control C57BL/6 and NOD and NODscid mice. Figure 2 shows mRNA expression of these molecules on Days 3 and 28 of postnatal life: FasL, Fas, and $\mathrm{Bcl}-2$ transcripts were detected in pancreata (or pooled pancreata) of the three mouse strains investigated. Although mRNA for these proteins were not detected in some samples, regardless of the strain, all samples were strongly positive when actin was amplified. When detected, mRNA for all molecules seemed to be stable during the first month of life and did not differ among the three strains.

The data presented above did not allow us to define differences between NOD and control mouse strains, in terms of gene expression for these molecules, and they did not give an idea of their respective tissue distributions. Therefore, the expression of these proteins was examined by immunohistochemistry.

\section{Numerous FasL ${ }^{+}$Structures in Mice with the NOD Genetic Background but Not in Control Strains from Birth Onward}

The most striking observation was the presence in NOD strains of abundant FasL ${ }^{+}$structures as shown in Figure 3. With regard to their localization, $\mathrm{FasL}^{+}$ structures appeared, from the earliest age investigated, to be located in subcapsular areas, in perivascular, periductular, and peri-islet areas, dispersed in the exocrine tissue, and sometimes under the peripancreatic capsula (Fig. 3, A to I). In control strains, they were scarce but similarly located (results not shown). The morphology and localization of $\mathrm{FasL}^{+}$structures 


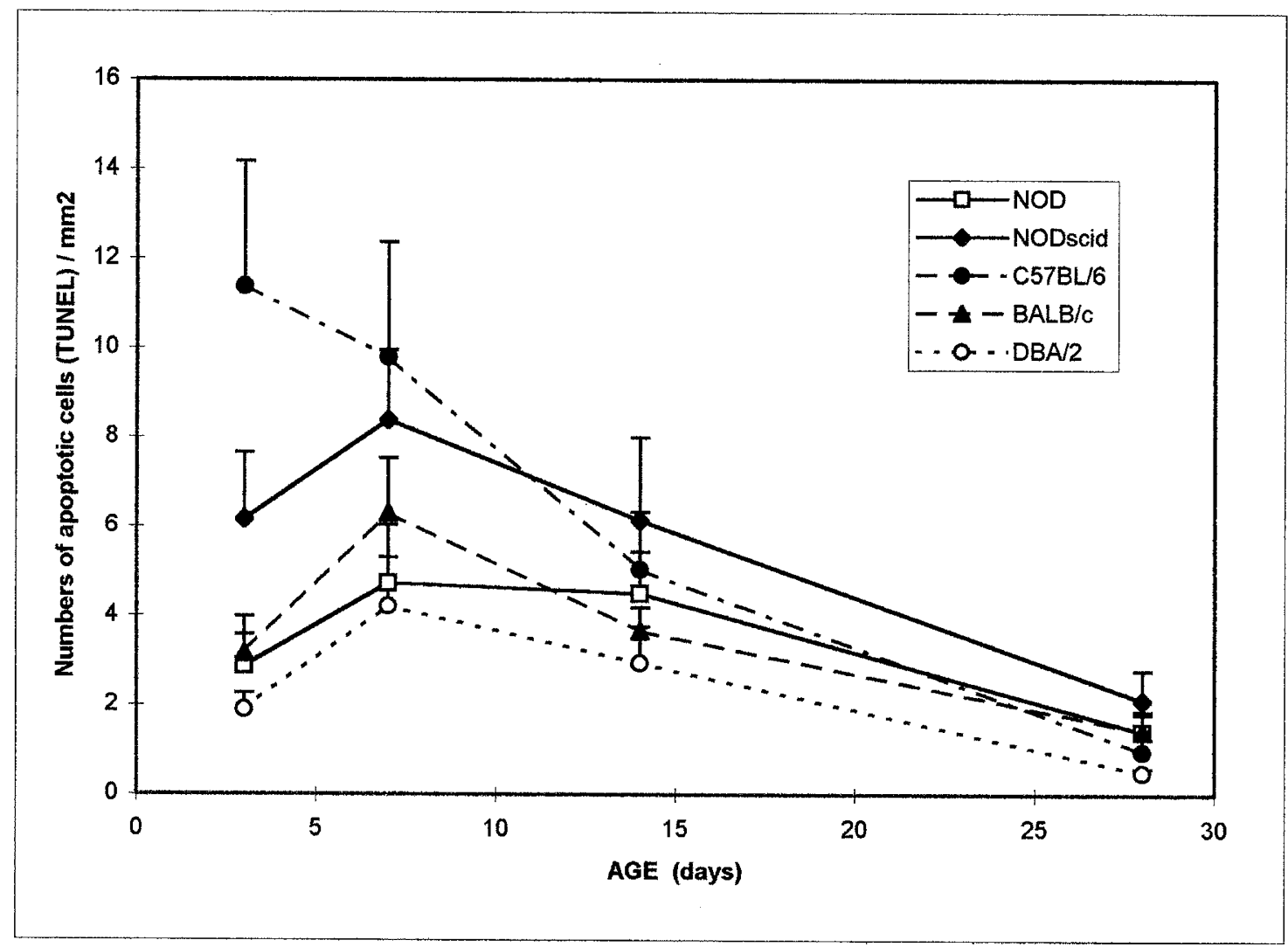

Figure 1.

Total numbers of pancreatic apoptotic cells present in control and nonobese diabetic (NOD) strains during the early postnatal period, as determined by the terminal transferase-mediated dUTP nick-end labeling assay. The numbers of positive cells were counted by two individuals and expressed per square millimeter of total pancreatic surface area. Mean values \pm SEM $(n=10$ mice per strain/age group).

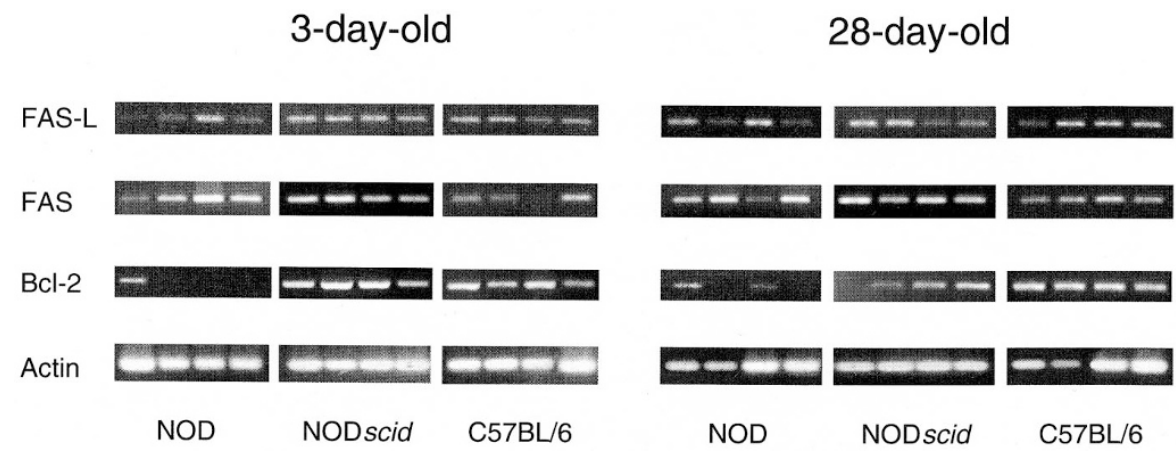

Figure 2.

Detection of fasL, fas, and $b c /$-2 genes in neonatal and young adult mouse pancreata. Four different pancreas extracts from 3-day-old and 28-day-old NOD, NODscid, and C56BL/6 mice are shown among the eight extracts analyzed per strain/age group. At 3 days of age, each extract corresponds to a pool of three pancreata and thereafter to individual glands. Pancreas extracts were subjected to RT-PCR for detection of fasL, fas, and $b c l-2$ and then subjected to electrophoresis on agarose gels and identified by their expected size (bp).

was suggestive of those associated with innervation, possibly neurons and/or their associated Schwann cells (Bechmann et al, 1999; Martin-Villalba et al, 1999; Raoul et al, 1999; Wohlleben et al, 2000).

Using C-178 anti-FasL Abs as for salivary glands (Cha et al, 2001), we quantified the $\mathrm{FasL}^{+}$structures per square millimeter of pancreas in the various strains as a function of age (Fig. 4). $\mathrm{FasL}^{+}$structures were abundant in NOD and NODscid pancreata from birth onward as compared with the three control strains.
This strain effect was highly significant $\left(p<10^{-6}\right.$, ANOVA). In particular, NOD mouse values were significantly higher than control strain counts at all ages ( $p$ $<10^{-4}$ in all cases, post-hoc analyses). For NODscid mice, these values were also significantly higher than those of control strains $\left(p<10^{-4}\right.$ at 3 days and at 1 and 2 weeks of age and $p<0.04$ at 4 weeks of age, post-hoc analyses). Moreover, significantly more $\mathrm{FasL}^{+}$structures were observed in NOD than NODscid mice at 3 days and at 1 and 4 weeks of age $(p<$ 


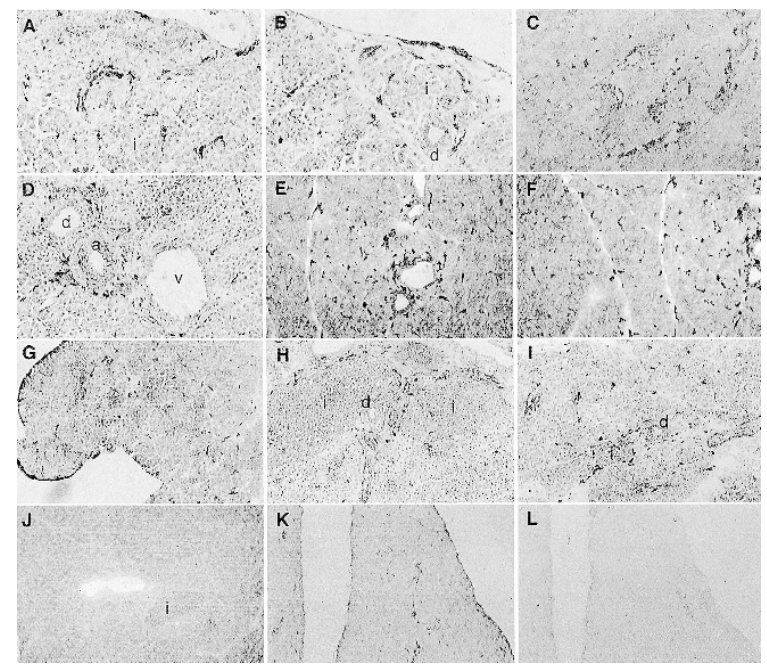

Figure 3.

Immunohistochemistry for Fas ligand (FasL) in control and NOD scid pancreata during the early postnatal period. A to C, 3-day-old NOD pancreata using the $\mathrm{C}-178 \mathrm{Ab}(\mathrm{A}$ and $\mathrm{B})$ or the $\mathrm{N}-20 \mathrm{Ab}(\mathrm{C})(\times 500)$. Note the FasL ${ }^{+}$structures scattered in the exocrine tissue, in peri-insular and periductular areas, and under the peripancreatic capsula. $D$ to $F, 2$-week-old $(D, \times 500)$ and 4-weekold $(E$ and $F, \times 320)$ NOD mice. FasL ${ }^{+}$structures $(C-178 \mathrm{Ab})$ are still present in perivascular, periductular, and peri-insular areas or scattered in the exocrine tissue and septa. G to I, 3-day-old (G), 1-week-old (H), and 2-week-old NOD scid (I) mice. FasL ${ }^{+}$structures (C-178 Ab) are present in the same sites as NOD mice $(\times 320)$. J, 4-week-old control DBA/2 mouse $(\times 200)$. Note the absence of FasL ${ }^{+}$structures in this field of a control pancreas, compared with age-matched NOD mice ( $E$ and F). $K$ and L, Blockage of FasL binding (K) after overnight incubation with the peptide antigen $(\mathrm{L})(\times 200)$

$\left.10^{-4}\right)$. A significant effect of age was also found $(p<$ $10^{-4}$, ANOVA). In NOD mice, $\mathrm{FasL}^{+}$structures were significantly more abundant at 3 days and at 1 week of age than at 2 and 4 weeks of age ( $p$ values from 0.02 to 0.00002 , post-hoc analyses). In NODscid mice, FasL also declined significantly between 3 days and 1 , 2 , and 4 weeks of age ( $p$ values from 0.02 to 0.00002 , post-hoc analyses) and between 1 and 2 weeks versus 4 weeks of age ( $p=0.02$ and 0.006 , respectively). By contrast, $\mathrm{FasL}^{+}$structures significantly increased between 2 and 4 weeks of age only in NOD mice $p=$ 0.04).

\section{Pancreas Innervation, a Privileged Site for Fas Expression in All Strains}

The next step was to investigate the expression of the apoptotic molecule Fas in all strains as a function of age. At 3 days of age, $\mathrm{Fas}^{+}$structures were observed (Fig. 5, A to C), either scattered in the pancreas or at its periphery. They appeared to be particularly numerous perinatally in strains with the NOD genetic background. In all strains regardless of the age, these Fas ${ }^{+}$ structures were highly suggestive of nerves (Fig. 5, A to I). This $\mathrm{Fas}^{+}$innervation was primarily located in peri-insular, perivascular, and periductular areas.

\section{Pancreas Innervation, Also a Privileged Site for Bcl-2 Expression in All Strains}

As shown in Figure 6, structures bearing the antiapoptotic protein $\mathrm{Bcl}-2$ were also observed in the mouse pancreas during the postnatal period. At 3 days of age, in pancreata of mice with the NOD genetic background, small scattered $\mathrm{Bcl}-2^{+}$structures were present (Fig. 6, A and B). In all strains regardless of the age, $\mathrm{Bcl}-2^{+}$structures, exhibiting the typical morphology of nerves, were present in the same locations as $\mathrm{Fas}^{+}$nerve-like structures, as clearly documented in Figure 6, C, G, and H. Finally, in 4-week-old mice with the NOD genetic background, abundant small $\mathrm{Bcl}-2^{+}$ structures were again detected in periductular and perivascular areas and also scattered in the exocrine tissue and septa (Fig. 6, D and E).

\section{Postnatal Pancreas Innervation, a Site for M $\phi$ Attraction and Interferon-Inducible Protein-10 (IP-10) Positivity, Even in Control Strains}

Labeling with antineurofilament 200 (NF200) Ab at 2 weeks of age in mice (Fig. 7, A to C) identified nerves scattered throughout the exocrine tissue, seen as more or larger trunks at the ductular-vascular pole of the islets and as a thin line at their periphery. Figure 7 (D to F) shows the expression of NF200, Bcl-2, or Fas in serial sections of a 4-week-old NOD mouse pancreas. A fine $\mathrm{NF}^{2} \mathrm{OO}^{+}$network, present in close proximity to a duct and an islet (Fig. 7D), appeared to be partly Bcl-2 ${ }^{+}$and $\mathrm{Fas}^{+}$(Fig. 7, E and F, respectively).

Taking into account the role, mentioned above, of $\mathrm{M} \phi$ during nervous tissue development, degeneration, and regeneration and the normal early pancreatic $\mathrm{M} \phi$ infiltration at sites where innervation is also thought to be present (ie, the islet and duct periphery), we searched for the presence of $\mathrm{M} \phi$ close to nerves. Figure 7 shows NF200 ${ }^{+}$innervation, located in close proximity to vessels and far from islets, in a control 4-week-old C57BL/6 pancreas (Fig. 7G) and surrounded by numerous ER-MP23 ${ }^{+} \mathrm{M} \phi$ and a few $\mathrm{BM}^{+} \mathrm{M} \phi$ (Fig. 7, $\mathrm{H}$ and I, respectively).

The next step was to determine whether innervation expresses chemokines that could potentially attract $\mathrm{M} \phi$ and lymphocytes (Bacon and Harrison, 2000; Hesselgesser and Horuk, 1999; Kieseier et al, 2000; Wang et al, 1998). For these experiments, we used 1 -week-old control mice, because the pancreas is still immature and contains high densities of various types of $\mathrm{M} \phi$ (Charré et al, 2002; Homo-Delarche, 2001). We used antiperipherin, instead of anti-NF200, because it is a better marker of innervation during axonal development (Portier et al, 1993). Double immunofluorescence labeling of peripherin and the chemokine IP-10 showed that large peripherin-positive nerve trunks near blood vessels were slightly IP- $10^{+}$(Fig. 7, J and $M$, respectively). Another example of fine peri-islet peripherin-positive innervation, also partly IP-10 positive, is seen in Figure 7 ( $\mathrm{K}$ and $\mathrm{N}$, respectively). Finally, at the same age, ER-MP23 ${ }^{+} \mathrm{M} \phi$ were observed surrounding a large peripherin-positive trunk, localized above an arteriole (Fig. 7, L and O, respectively). It should be noted that, in Figure 7 ( $\mathrm{M}$ and $\mathrm{O}$ ), the arterioles (most probably their elastin) appeared strongly positive when using two different labeling techniques for unrelated markers (IP-10 and ER- 


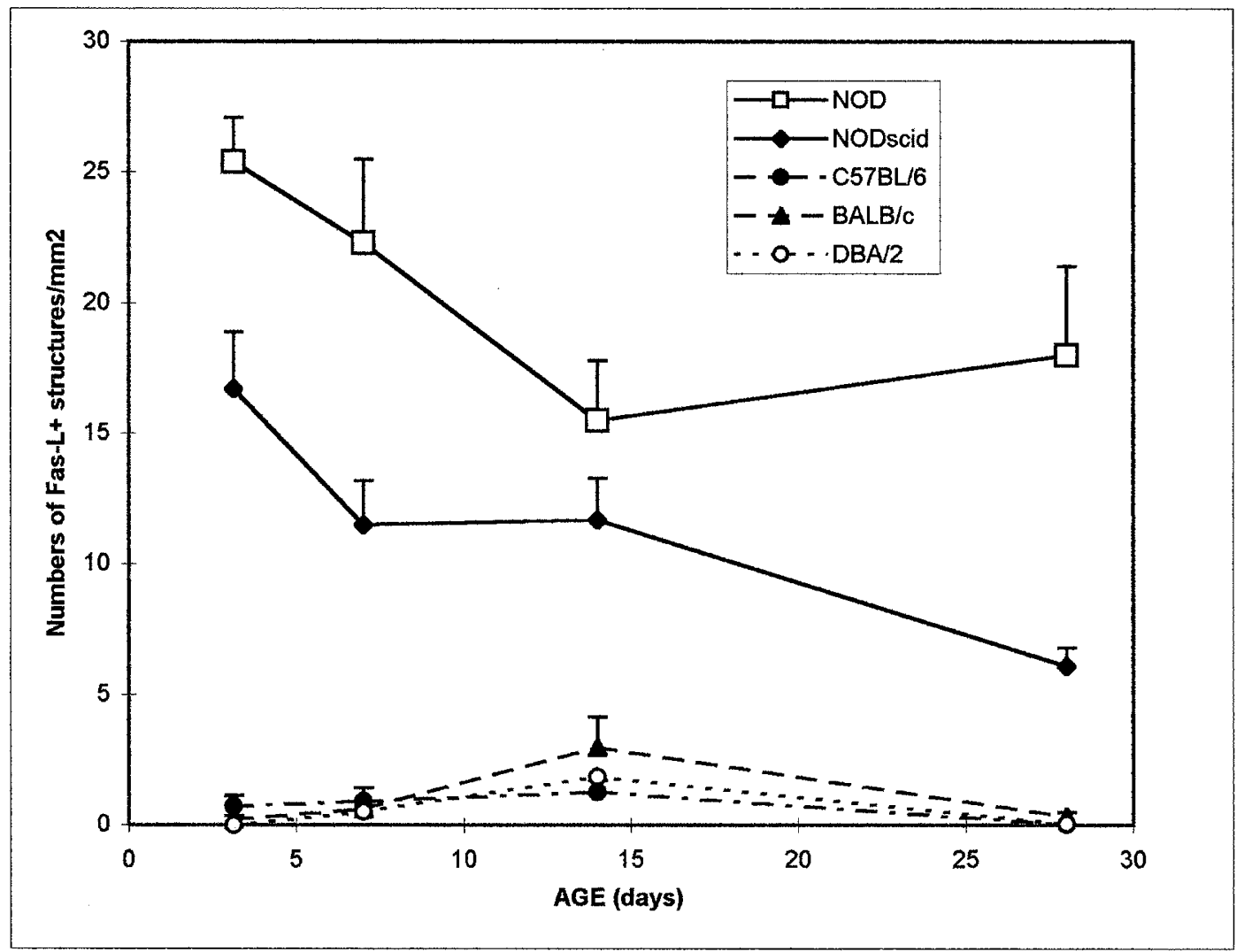

Figure 4.

Numbers of FasL ${ }^{+}$structures, determined using the $\mathrm{C}-178 \mathrm{Ab}$, in the pancreata of control and NOD strains during the early postnatal period. The numbers of FasL ${ }^{+}$ structures were counted and expressed as in Figure 1. Mean values \pm SEM ( $n=10$ mice per strain/age group).

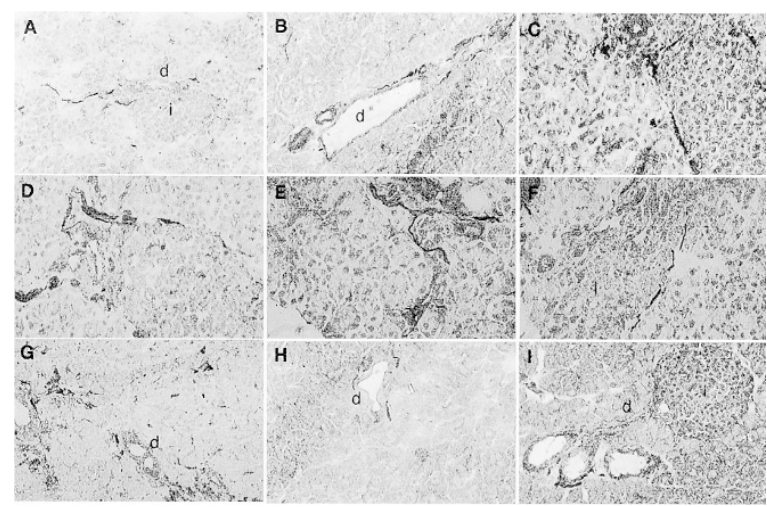

Figure 5.

Immunohistochemistry for Fas in control and NODscid pancreata during the early postnatal period. A to $\mathrm{C}, 3$-day-old NOD $(\mathrm{A}, \times 500)$, NODscid $(\mathrm{B}, \times 500)$, and control C57BL/6 $(C, \times 800)$ mouse pancreata. Note the Fas positivity in nerve-like structures localized near or around islets and ducts in all strains. D to $F$, 1-week-old NOD (D), NODscid (E), and DBA/2 (F) mouse pancreata $(\times 800)$. Fas ${ }^{+}$nerve-like structures are present at the ductular pole of the islet, around the islet and acini. $\mathrm{G}$ to I, 4-week-old NOD (G, $\times 320)$, NODscid $(\mathrm{H}$ $\times 500)$, and control C57BL/6 $(\mathrm{I}, \times 500)$ mouse pancreata. Fas $^{+}$nerve-like structures are still present at the periphery of vessels, ducts, and islets in all strains.

MP23), either extravidin-FITC, which binds to biotin conjugated to the second $\mathrm{Ab}$ (Fig. 7M) or a second directly-labeled Ab (Fig. 7O). These images suggest the probably nonspecific autofluorescence of these structures. Finally, similar patterns of IP-10, peripherin, and ER-MP23 labeling were obtained in 1-weekold NOD mouse pancreata (results not shown).

\section{Discussion}

The expression of proapoptotic and antiapoptotic proteins, together with apoptosis, is shown here for the first time during early postnatal pancreas development in several mouse strains (three control and two NOD-related strains). First, although no major difference in the numbers of total pancreatic apoptotic cells was noted among strains, $\mathrm{FasL}^{+}$expression was significantly higher in mice with the NOD genetic background than in control pancreata from birth to 1 month of age. Second, $\mathrm{FasL}^{+}, \mathrm{Fas}^{+}$, and $\mathrm{Bcl}-2^{+}$ structures seemed to be associated with innervation, regardless of the strain and age. Third, in control and NOD strains, nerves expressed the chemokine IP-10 and various types of $\mathrm{M} \phi$ are present in close proximity to them.

Total numbers of pancreatic apoptotic cells were low and roughly similar in all strains during the first month of life with the exception of C57BL/6 mice, which had more apoptotic cells than all other strains at 3 days of age, followed by a progressive decline from birth to 1 month of age. In all strains, these apoptotic cells were scattered throughout the pancreas and not localized to a particular pancreatic structure. These 

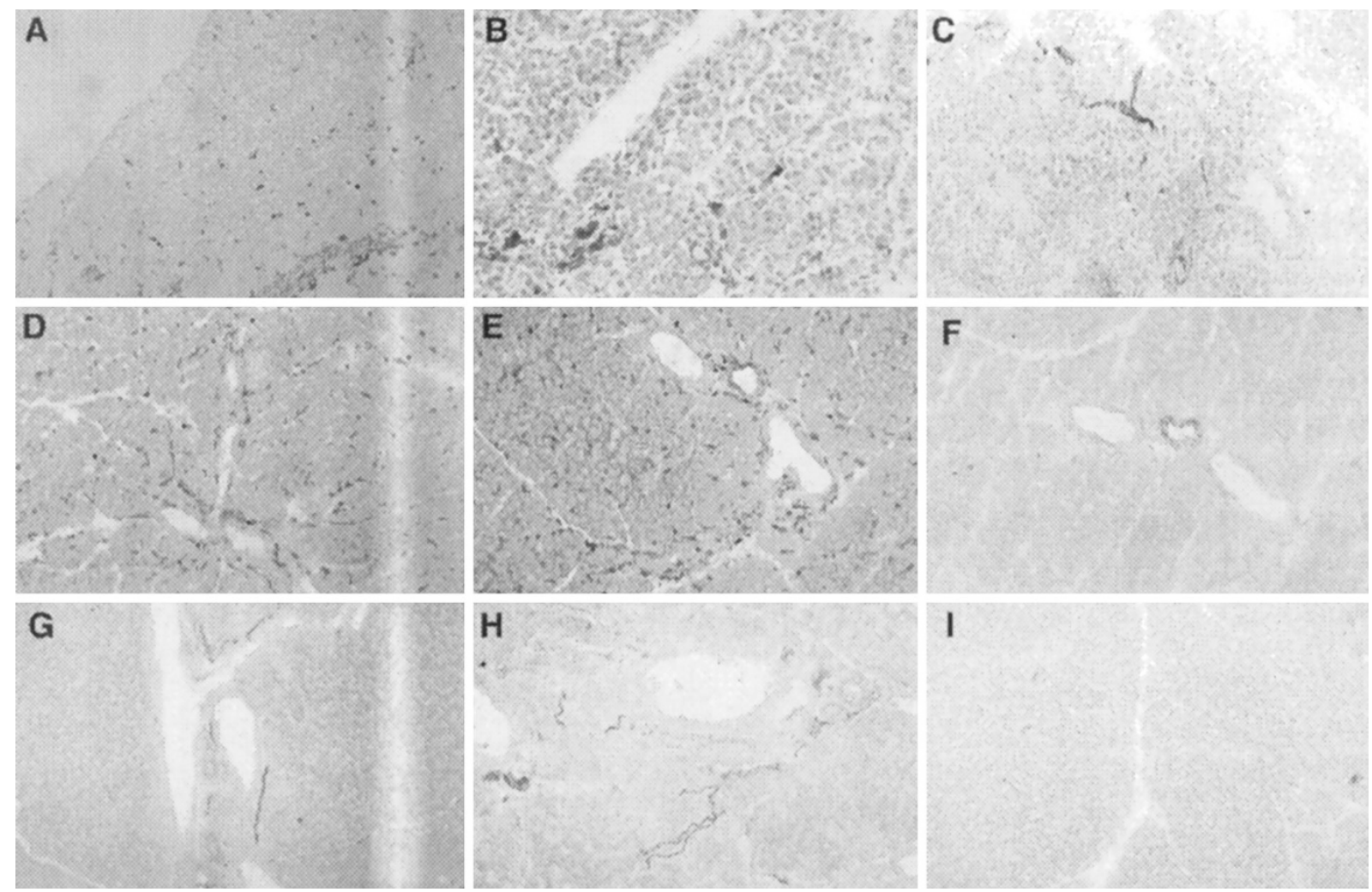

I

Figure 6

Immunohistochemistry for Bcl-2 in control and NODscid pancreata during the early postnatal period. A to C, 3-day-old NOD (A, $\times 200)$, NODscid (B, $\times 500)$, and control C57BL/6 $(\mathrm{C}, \times 500)$ pancreata. Note the numerous Bcl-2+ structures scattered in the exocrine tissue in NOD and NODscid pancreata and the less abundant Bcl-2 nerve-like structures in control mice $(C)$. D to F, 4-week-old NOD pancreata $(\times 200)$. Numerous Bcl-2 ${ }^{+}$structures are scattered in the exocrine tissue and septa and at the periphery of vessels and ducts ( $D$ and $E) ; F$, a serial section of $(E)$ is the negative control. G to I, 4-week-old control DBA/2 (G and H, $\times 200$ and $\times 500$, respectively) and C57BL/6 $(\mathrm{I}, \times 200)$ pancreata. Rare and fine nerve-like structures are present in some but not all sections, unlike what was observed in NOD mice $(\mathrm{D}$ and $\mathrm{E})$.

data are in agreement with a previous study, which showed that apoptotic cells were not only $\beta$ cells but also pancreatic acinar and ductal cells (Finegood et al, 1995). However, $\beta$-cell apoptosis was found to peak in rats at postnatal Day 5 or between Days 10 and 14 (Hanke, 2000; Petrik et al, 1998; Scaglia et al, 1997), whereas apoptosis has been described as increasing in NOD mice from birth onward (Trudeau et al, 2000).

Immunohistochemical studies revealed significantly higher densities of $\mathrm{FasL}^{+}$structures in NOD and NODscid mice than in all control strains, in which they are present but rare. However, $\mathrm{FasL}^{+}$structures were similarly located in all strains, either scattered in the exocrine tissue or, more often, concentrated in perivascular, periductular, and peri-islet areas. At birth, they could be observed clustered at the periphery of the pancreas. Few data are available on spontaneous pancreatic FasL expression in young rodents. In rat islets, FasL was detected during the first 3 days of life and disappeared thereafter (Hanke, 2000). In young adult control and NOD mice, FasL was not observed in islet $\beta$ cells (Thomas et al, 1999) but was observed in surrounding $\alpha$ cells (Signore et al, 1997). Our observations confirm the absence of FasL expression in mouse $\beta$ cells under normal conditions.

The irregular labeling pattern of $\mathrm{FasL}^{+}$structures in size, length, and density led us to think of innervation
(Honjin, 1956; Legg, 1968). As shown in Figure 8, special attention was accorded long ago to the presence of a very dense nerve network in and around the islet of Langerhans (Honjin, 1956). Since that time, neural islet-cell regulation has been studied extensively (Gilon and Henquin, 2001; Sorenson et al, 1991), but its particular localization was overlooked until the presence of the neuroinsular complexes was recently reemphasized (Persson-Sjogren, 2001; Sunami et al, 2001). During nervous tissue development and concomitant apoptotic phenomena, FasL is expressed on neurons and their closely associated Schwann cells, which are immunoreactive for glial fibrillary acidic protein (Bechmann et al, 1999; Martin-Villalba et al, 1999; Raoul et al, 1999; Wohlleben et al, 2000). Schwann cells are known to surround the islets of Langerhans (Teitelman et al, 1998), but the immunohistochemical labeling pattern of glial fibrillary acidic protein did not resemble that of FasL in our studies.

We were able to demonstrate Fas immunoreactivity in mouse pancreatic innervation, particularly in periislet and periductular localizations. Fas was not detected in rat islet $\beta$ cells during the postnatal period or in young adult mice, including NOD, in agreement with our data (Hanke, 2000; Signore et al, 1997; Thomas et al, 1999). Neurons and Schwann cells can express both Fas and FasL, and this coexpression is thought 

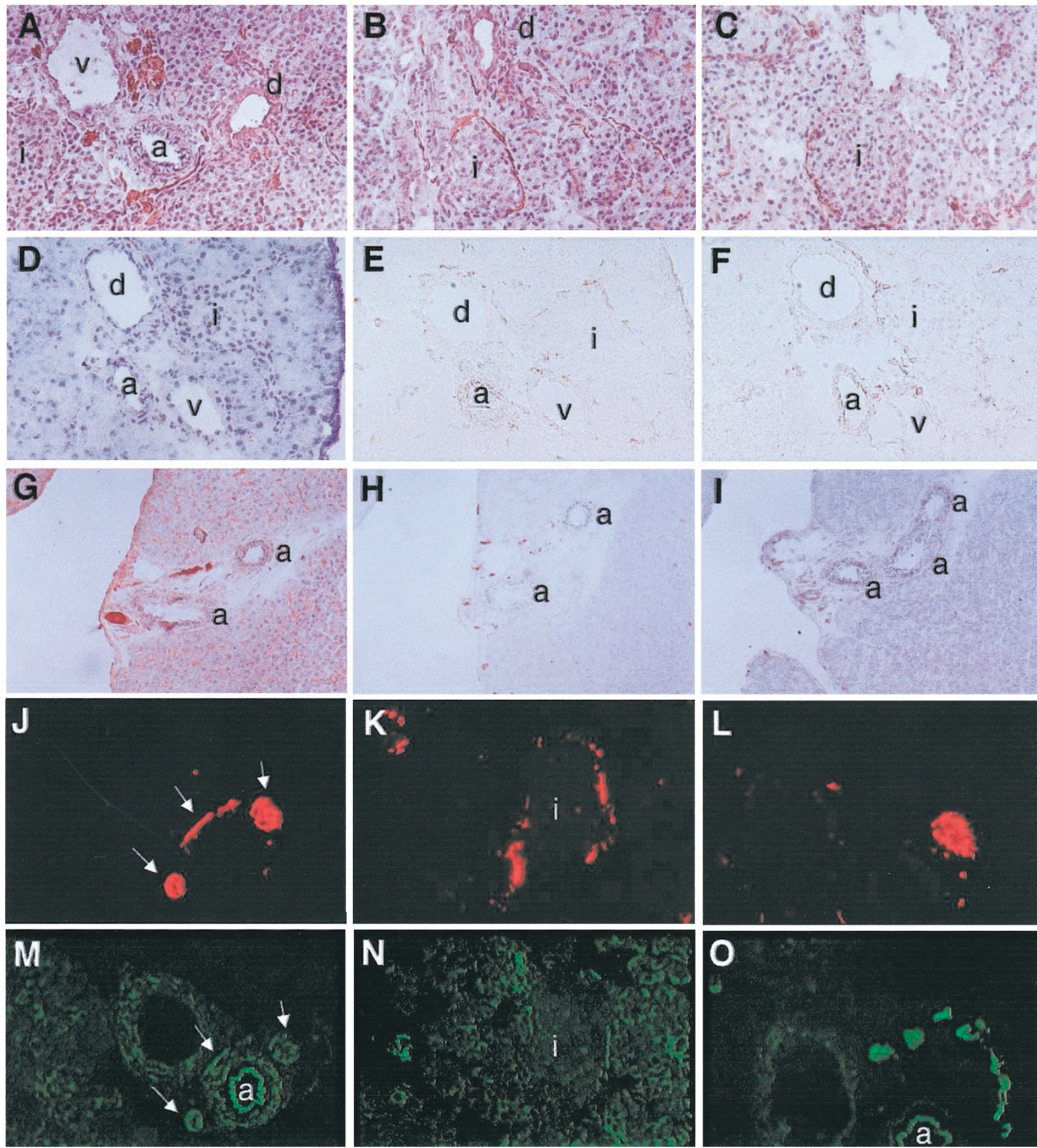

\section{Figure 7.}

Relationships among pancreatic innervation, macrophages $(\mathrm{M} \phi)$, and chemokines. A to C, Immunohistochemistry for NF200 in 2-week-old control (A and B) and NODscid (C) pancreata. Note the fine neurofilament 200-positive (NF200 ${ }^{+}$) fibers at the islet periphery and also the large NF200 ${ }^{+}$trunks in perivascular and ductular areas $(\times 500)$. D to F, NF200, Bcl-2, and Fas immunohistochemistry in serial sections of a 4-week-old NOD mouse pancreas. NF200 innervation is present at the duct and islet periphery (D), and part of this innervation seems to be $\mathrm{Bcl}^{-} 2^{+}(\mathrm{E})$ or Fas ${ }^{+}(\mathrm{F})(\times 500)$. G to I, Immunohistochemistry for NF200 (G) and M $\phi(E R-M P 23$ and $\mathrm{BM} 8, \mathrm{H}$ and I, respectively) in serial pancreas sections from a 4-week-old control C57BL/6 mouse. Note the perivascular NF200 ${ }^{+}$innervation, which is surrounded by many ER-MP23 ${ }^{+} \mathrm{M} \phi$ and a few BM8 ${ }^{+}$cells $(\times 320)$. $\mathrm{J}$ to 0 , Double immunofluorescence labeling for peripherin, another marker of innervation, and the chemokine interferon-inducible protein-10 (IP-10) or ER-MP23 ${ }^{+} \mathrm{M} \phi$ in the pancreas of a 1-week-old control C57BL/6. $J$ and M, Double immunofluorescence labeling of peripherin $(\mathrm{J})$ and IP-10 (M) (white arrows point to the structures in which peripherin and IP-10 appear to be colocalized; $\times 200$ ). Note that peripherin-positive innervation is weakly positive for IP-10. Arterioles appear to be strongly positive because of their high autofluorescence. $\mathrm{K}$ and $\mathrm{N}$, Double immunofluorescence for peripherin $(K)$ and IP-10 $(N)(\times 400)$. Part of innervation at the periphery of the islet is also weakly IP-10+. $L$ and 0 , Double immunofluorescence for peripherin $(\mathrm{L})$ and ER-MP23 (0) (×800). Note the large peripherin-positive nerve trunk above an arteriole, which is surrounded by ER-MP23 ${ }^{+} \mathrm{M} \phi$.

to contribute to neuron loss during normal nervous system development (Park et al, 1998; Raoul et al, 1999; Wohlleben et al, 2000).

As shown here, the antiapoptotic protein $\mathrm{Bcl}-2$ is also linked to nervous structures in the mouse pan- creas. To the best of our knowledge, pancreatic Bcl-2 expression has never been investigated in mice, but in postnatal and adult rats, it is more or less weakly expressed by duct cells (Bouwens and De Blay, 1996; Wada et al, 1997), a feature that we did not observe in 


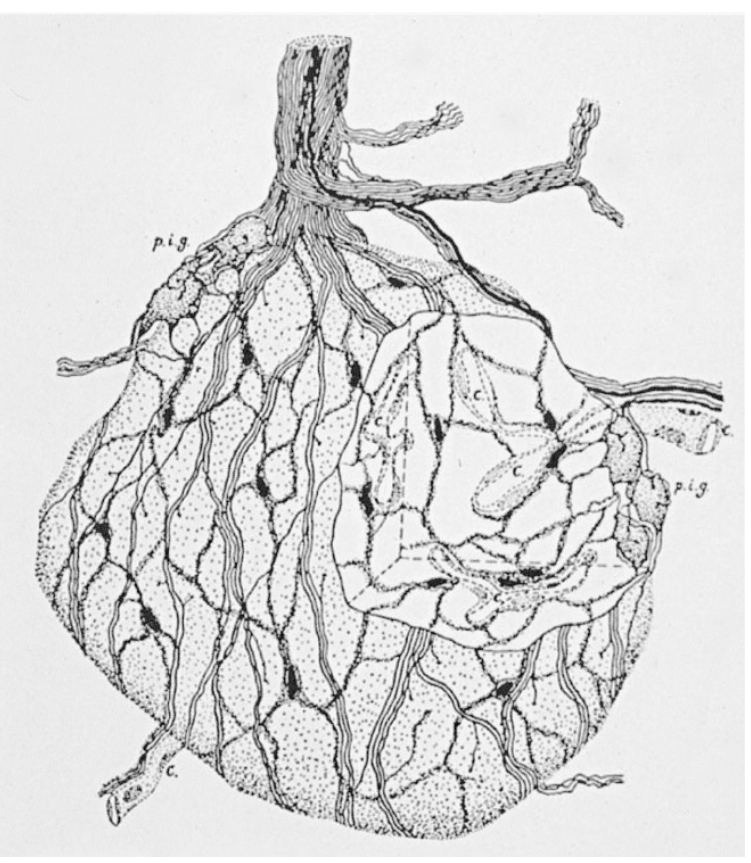

Figure 8.

Innervation of an islet of Langerhans in mouse pancreas drawn by Honjin (1956). From the large nerve trunk at one pole of the islet emerges the peri-insular plexus, the peri-insular ganglia (p.i.g.), and the "neural terminal" net in and around the islet. The neural terminal is said to be composed of nerve fibers and interstitial Cajal's cells (in black). Part of the islet has been excised to show the interior structure of the islet. $c=$ capillary, $\times 800$. (From Honjin, 1956; courtesy of John Wiley \& Sons, Inc).

mice. Depending on the study, $\mathrm{Bcl}-2$ has been shown to be expressed or not by duct cells and/or nervous constructions (Campani et al, 2001; Kobayashi et al, 2000; Miyamoto et al, 1999). Bcl-2 is widely expressed during embryonic development of the CNS and peripheral nervous systems (PNS), and its persistence in the adult PNS is consistent with a $\mathrm{Bcl}-2$ role in the regulation of neuron survival, as demonstrated in Bcl-2-deficient and transgenic mice (Farlie et al, 1995; Greenlund et al, 1995).

Postnatal apoptosis, also called "programmed cell death," particularly of sympathetic innervation, is well recognized (Burek and Oppenheim, 1996; Saikumar et al, 1999). As mentioned above, during CNS and PNS development as well as that of the eye, neuron apoptosis is associated with the presence of $M \phi$. In the normal neonatal mouse pancreas, high numbers of various types of $\mathrm{M} \phi$, including those with scavenger potential, are observed at birth and progressively diminish thereafter (Charré et al, 2002). Almost nothing is known about what happens to innervation in a peripheral organ, such as the pancreas, which is still developing after birth. Therefore, the chemokine IP10 , which is present during normal postnatal pancreas development in innervation, might attract leukocytes for tissue remodeling.

Apoptosis is considered to be a cell death pathway that does not involve an inflammatory response. However, in certain circumstances, apoptotic cells may induce an immune reaction that can increase the susceptibility to or even lead to the development of an autoimmune disease (Fadok et al, 2001; Marrack et al, 2001; Mevorach et al, 1998; Platt et al, 1998; Rosen and Casciola-Rosen, 2001). Autoimmunity could develop when $\mathrm{M} \phi$ anomalies exist, such as those already documented in NOD mice, which include defective differentiation from bone marrow precursors, abnormal $F c \gamma R / l$ gene expression, altered cytokine secretion, and enhanced arachidonic acid metabolism (Lety et al, 1992; Luan et al, 1996; Piganelli et al, 1998; Radosevic et al, 1999; Serreze et al, 1993). In this context, the recently described reduced phagocytic ability of NOD M $\phi$ should be underlined (O'Brien et al, 2002).

We therefore postulate that $\mathrm{M} \phi$ abnormalities might disturb developmental in vivo tissue remodeling and provide a cellular microenvironment favoring organtargeted autoimmunity (Homo-Delarche, 2001). This hypothesis is reinforced by recent observations of the salivary gland, another target of the autoimmune reaction in NOD mice (Cha et al, 2001). Delayed morphologic differentiation, observed in 1-day-old salivary glands, was associated throughout the preweaning period with increased activities of matrix metalloproteinases 2 and 9. Moreover, Fas, FasL, and Bcl-2 were also more strongly expressed at birth and were localized around ducts and acini. Intriguingly, all these structures resembled nerves, which are known to be present in these exact locations (Kusakabe et al, 1997), as are the first infiltrating antigen-presenting cells (van Blokland et al, 2000), a finding reminiscent of our present data in the pancreas. Moreover, studies on salivary hypofunction in NOD mice showed autoantibodies and T-cell reactivity with neuron-specific reactivity (Esch and Taubman, 1998).

Finally, some Abs found in human T1D, such as anti-GAD, anti-ICA 512, and anti-glima 38, are directed against proteins common to $\beta$ cells and neurons (Homo-Delarche, 1997, 2001). Furthermore, autoreactive $\mathrm{T}$ cells that routinely target classical islet autoantigens and CNS autoantigens also exist in T1D patients, their relatives with high diabetic risk, NOD mice, and patients with multiple sclerosis (Winer et al, 2001a, 2001b). In NOD mice, more particularly, autoantibodies directed against an antigen identified as peripherin and T-cell reactivities against GAD 67 and peripherin have been observed as early as 4 to 6 weeks of age (Boitard et al, 1992; Tisch et al, 1993), when we also showed early leukocyte infiltration around GAD-containing (sympathetic) fibers, followed by a progressive disappearance of these fibers (Saravia-Fernandez et al, 1996). At 4 to 8 weeks of age, NOD and NODscid mice already present paradoxical but transient hyperinsulinemia, which is preceded by perinatal and also transient $\beta$-cell hyperactivity (Rosmalen et al, 2002). Because acute changes of glucose levels modify neural activity and the latter controls islet-cell secretion, it could be hypothesized that innervation is not a passive actor, at least in NOD mice, and already controls events at the fetal level in association with abnormal maternal glucose homeostasis and, later, during the postweaning period. Therefore, early immune events, as recently high- 
lighted (Greeley et al, 2002), and neuroendocrine phenomena might concomitantly be at work early during the pathogenesis of autoimmune diabetes in NOD mice.

\section{Materials and Methods}

\section{Animals}

NOD, NODscid, C57BL/6, DBA/2, and BALB/c female mice were housed and bred under specific pathogenfree conditions at the animal facilities of Hôpital Necker, Paris, France, in accordance with the rules established by the European Community. By 200 days of age, the incidence of diabetes in our NOD colony is $80 \%$ for females. Regarding the immunohistochemical analysis of Fas, FasL, Bcl-2, and TUNEL, mice of various strains were killed on Day 3, 7, 14, or 28 after birth. For these experiments, 10 animals of each strain per age group were used. For RT-PCR analyses, eight additional mice of each strain per age group were killed.

\section{RT-PCR Studies}

Purification of RNA and cDNA Synthesis. Total RNA was extracted from mouse pancreata using RNAble reagent (Eurobio, Les Ulis, France) according to the manufacturer's instructions. After isopropanol precipitation, the RNA pellet was dissolved in $50 \mu$ l of diethyl pyrocarbonate-treated water, and RNA concentrations were measured by OD at $260 \mathrm{~nm}$. Then, $40 \mathrm{U}$ of RNasin (Promega, Charbonnières, France) was added to the samples, which were stored at $-80^{\circ} \mathrm{C}$. Each sample corresponded to an individual animal, except for Day 3, when three pancreata were pooled. For cDNA synthesis, the reverse transcription system from Promega was used according to the manufacturer's instructions. Total mouse pancreatic RNA $(2 \mu \mathrm{g})$ was reverse transcribed in the presence of Oligo dT15 (Promega) and random hexamers in a total volume of $40 \mu \mathrm{l}$.

Quality Control of RNA Samples. For better control of the RNA preparations and reverse transcription efficiency, we studied the expression of a housekeeping gene, glyceraldehyde-3-phosphate dehydrogenase, using real-time PCR methodology. For this purpose, we used an $\mathrm{ABI}$-prism 7700 sequence detector (PE applied, Courtaboeuf, France) with the PE applied kit. The presence of GAPDH cDNA was evaluated in each reverse-transcribed sample, according to the manufacturer's instructions. A standard curve (from 15 $\times 10^{3}$ to $1.5 \mathrm{pg}$ of starting pancreatic total RNA, measured by OD at $260 \mathrm{~nm}$ ) was established from one cDNA preparation. GAPDH was then measured in all samples with reference to this standard curve. Because the standard curve values did not reflect the true RNA levels present, results are expressed in arbitrary units. Samples containing $<5000$ arbitrary units were excluded from the study.

Analysis of mRNA Expression. Fas, FasL, and Bcl-2 cDNAs sequences were amplified by PCR using specific primers, which were designed using the primer express software and the available gene sequences, and the oligomers purchased from Cybergene (Evry, France) (Table 1). The volume of each reaction mixture was $25 \mu \mathrm{l}$ and contained a final concentration of 100 mм Tris- $\mathrm{HCl}$ (pH 8.3); $50 \mathrm{~mm} \mathrm{KCl;} 2$ mм (FasL), $1 \mathrm{~mm}$ (Fas), or $1.2 \mathrm{~mm}(\mathrm{Bcl}-2) ; \mathrm{MgCl}_{2} ; 0.2 \mathrm{~mm}$ deoxynucleotide triphosphate; $0.05 \mu \mathrm{M}$ of sense and antisense primers, $2 \mu \mathrm{l}$ of undiluted cDNA; and $0.8 \mathrm{U}$ of Taq platinum DNA polymerase (Life Technologies, CergyPontoise, France). Actin, used as internal standard, was also amplified from each cDNA sample. After a 5 -minute initial period at $94^{\circ} \mathrm{C}$, samples were amplified through 35 cycles for 50 seconds at $94^{\circ} \mathrm{C}, 1$ minute at optimal annealing temperature $\left(52^{\circ} \mathrm{C}\right.$, $58^{\circ} \mathrm{C}$, or $62^{\circ} \mathrm{C}$ for Fas, FasL, or Bcl-2, respectively), and 1 minute at $72^{\circ} \mathrm{C}$. The final elongation time was 5 minutes at $72^{\circ} \mathrm{C}$. Of $25 \mu \mathrm{l}$ of total PCR volume, $16 \mu \mathrm{l}$ was subjected to electrophoresis through $2 \%$ agarose gels, which were stained with ethidium bromide, visualized with UV, and photographed. For a given age, three mouse strains, C57BL/6 (control), NOD, and NODscid, were analyzed on the same gel.

\section{Immunohistochemistry Protocols}

Samples. Mice of different strains were killed by cervical dislocation. Their pancreata were removed,

Table 2. General Characteristics of Primary Polyclonal Abs Used to Detect Proapoptotic and Antiapoptotic Molecules

\begin{tabular}{ccc}
\hline \multicolumn{1}{c}{ Primary Ab } & $\begin{array}{c}\text { Molecular Specificity } \\
\text { for Mouse Tissues }\end{array}$ & Dilution \\
\hline anti-FasL (C-178) & $\begin{array}{l}\text { Residues 100-278 } \\
\text { (carboxy terminus) }\end{array}$ & $1: 500$ \\
anti-FasL (N-20) & $\begin{array}{l}\text { Peptide mapping at the } \\
\text { amino terminus }\end{array}$ & $1: 500$ \\
anti-Fas (Ab-1) & $\begin{array}{l}\text { Residues 321-335 } \\
\text { anti-Bcl-2 }\end{array}$ & $\begin{array}{l}\text { Residues 4-21 (amino } \\
\text { terminus) }\end{array}$ \\
& 1:40 \\
\hline
\end{tabular}

Table 1. PCR Primers and Annealing Temperatures ( $\left.\mathrm{Tm}^{\circ}\right)$ Used for the Semiquantitative RT-PCR Study

\begin{tabular}{cllcc}
\hline Molecule & \multicolumn{1}{c}{ Sense Nucleotide Sequence } & Antisense Nucleotide Sequence & Tm & $\begin{array}{c}\text { Amplicon } \\
\text { (bp) }\end{array}$ \\
\hline Fas-L & GCAGAAGGAACTGGCAGAACTCCGTG & GGCTGGTTGTTGCAAGACTGACCC & 62 & 352 \\
Fas & CTGCGATTCTCCTGGCTGTG & CCCTCCTTGATGTTATTTC & 52 & 357 \\
Bcl-2 & GCATCTTCTCCTTCCAGCCT & CACCTACCCAGCCTCCGTTA & 58 & 444 \\
Actin & TAAAGACTTCTATGCCAACACAGT & CACGATGGAGGGGCCGAACTCACT & 53 & 240 \\
\hline
\end{tabular}


embedded in OCT (Tissue-Tek, Miles, Elkart, Indiana), and frozen in $\mathrm{n}$-hexane on dry ice-chilled alcohol. Tissues were stored at $-80^{\circ} \mathrm{C}$ until immunohistochemistry was performed. Cryostat sections $(6-\mu \mathrm{m}$ thick) were prepared from central regions of the pancreas and mounted on microscope slides.

Immunoperoxidase Labeling. Sections were fixed for 5 seconds in cold methanol followed by $15 \mathrm{sec}$ onds in acetone at room temperature. After washing in PBS (pH 7.8), endogenous biotin-like structures were blocked using an avidin-biotin blocking kit (AbCys, Paris, France). Then, sections were washed with PBS and incubated for 1 hour at room temperature with primary polyclonal Abs to Fas, FasL, or Bcl-2; characteristics of the Abs are given in Table 2. The sections were washed with PBS and incubated for either 30 minutes (Fas) or 45 minutes (FasL and $\mathrm{Bcl}-2$ ) with biotinylated goat anti-rabbit IgG (Dako, Trappes, France) diluted $1: 100$ in PBS-0.1\% BSA containing $2 \%$ normal mouse serum. After washing with PBS, the sections were incubated for 45 minutes (Fas) or 30 minutes (FasL and $\mathrm{Bcl}-2$ ) with horseradish peroxidase-conjugated avidin-biotin complex (Dako) diluted 1:100 in PBS. The sections were again washed with PBS and the labeling visualized by exposure to $0.01 \%$ (w/v) diaminobenzidine. After washing with PBS, the slides were counterstained with nuclear fast red (Fluka, L'Isle d'Abeau Chesnes, France) and mounted with Depex Faramount medium (Dako). The specificity of Fas, FasL, or Bcl-2 immunolabeling was assessed as follows: (a) omission of the primary $A b$, which eliminates immunoreactivity; (b) decrease of the signal intensity as the primary Ab dilution was increased; (c) finally, blocking assay, in which each $\mathrm{Ab}$ was incubated overnight at $4^{\circ} \mathrm{C}$, with a 20 -fold excess of peptide (Santa Cruz Biotechnology, Le Perray-enYvelynes, France [FasL], and Calbiochem, Meudon, France [Fas and Bcl-2]). After incubation, the neutralized $A b$ was used instead of primary $A b$ and, in this case, no labeling was observed.

To study innervation, a rabbit anti-bovine NF200 (diluted 1:200; Sigma) was added to the sections for 30 minutes, followed by the addition of swine antirabbit peroxidase (diluted 1:100; Dako) for 30 minutes with appropriate washes as described above.

$\mathrm{M} \phi$ were labeled with ER-MP23, a rat anti-mouse macrophage galactose-specific lectin, used as undiluted hybridoma-culture supernatant. ER-MP23 positivity characterizes histiocyte-type $M \phi$, which are normally present, even neonatally, in pancreatic connective tissue and migrate in NOD mice to the periphery of ducts and the islets, where some of them penetrate into the latter (Charré et al, 2002; Jansen et al, 1994; Leenen et al, 1994). BM8, a rat anti-mouse Ab (BMA Biomedicals AG, Augst, Switzerland) that identifies a $125-k D a$ cell-surface protein was also used, diluted 1:50 (Jansen et al, 1994; Leenen et al, 1994). BM8 is expressed by histiocytes and $M \phi$ with scavenging potential. $\mathrm{BM}^{+}$cells are normally present in neonatal control and NOD pancreata and migrate into NOD islets once lymphocytes have been recruited (Charré et al, 2002). BM8 and ER-MP23 binding was detected with horseradish peroxidase-conjugated rabbit anti-rat Ig (Dako) diluted 1:100.

Immunofluorescence Labeling. Pancreas sections were fixed with acetone containing $0.03 \% \mathrm{H}_{2} \mathrm{O}_{2}$ and blocked with avidin-biotin as described above. Then they were incubated for 2 hours with goat anti-mouse IP-10 (Santa Cruz Biotechnology) diluted 1:75, followed by a 1-hour incubation with a biotin-conjugated donkey anti-goat Ig Ab (Tebu, Le Perray-en-Yvelines, France) and extravidin-FITC (Sigma) (diluted 1:450 and 1:475, respectively). Thereafter, slides were incubated with rabbit anti-mouse peripherin (30 minutes at 1:50 dilution), followed by a 30-min incubation with a goat anti-rabbit Ig Ab, conjugated with TRITC (dilution 1:80; Biosys, Compiègne, France).

For double labeling of $\mathrm{M} \phi$, slides were first incubated for 1 hour with rat anti-mouse ER-MP23 supernatant and then for 30 minutes with a goat anti-rat Ig conjugated with FITC (dilution 1:200; Jackson Immunoresearch Laboratories, Inc., West Grove, Pennsylvania) followed by anti-peripherin labeling as described above.

In Situ Apoptosis Detection. Sections used for the TUNEL assay were fixed for 10 minutes in a $4 \%$ paraformaldehyde solution ( $\mathrm{pH}$ 7.4) (Merck, Nogentsur-Marne, France) at $4^{\circ} \mathrm{C}$, washed in PBS ( $\left.\mathrm{pH} 7.8\right)$, postfixed with ethanol/glacial acetic acid $(2 / 1, \mathrm{v} / \mathrm{v})$ at $-20^{\circ} \mathrm{C}$, and again washed with PBS. For positive controls, two sections were incubated at $37^{\circ} \mathrm{C}$ successively in DNAse buffer (10 mm Tris, $10 \mathrm{~mm} \mathrm{NaCl,} 5$ $\mathrm{mm} \mathrm{MgCl}_{2}$ ) for 5 minutes and in DNAse I solution (200 $\mathrm{ng} / \mathrm{ml}$; Roche Diagnostics, Meylan, France) for 15 minutes. Thereafter, all sections were incubated with $50 \mu \mathrm{l}$ of terminal deoxynucleotidyl transferase (TdT) buffer (100 mm sodium cacodylate, $1 \mathrm{~mm}$ cobalt chloride, $0.01 \mathrm{~mm}$ dithiothreitol, and $0.005 \%$ BSA) for 5 minutes at $37^{\circ} \mathrm{C}$. Subsequently, $50 \mu \mathrm{l}$ of TdT solution containing $20 \mathrm{U}$ of TdT (Promega), $20 \mu \mathrm{M}$ deoxynucleotide triphosphate (dNTP) (Promega), and $2 \mu \mathrm{M}$ digoxigenin-labeled dUTP (Roche Diagnostics) were added for 1 hour at $37^{\circ} \mathrm{C}$. As a negative control, TdT was omitted. Then, the reaction was stopped by washing for 30 minutes at $37^{\circ} \mathrm{C}$ with $2 \times$ SSC (Promega). Sections were sequentially washed with PBS and TNT (100 mm Tris- $\mathrm{HCl}, 150 \mathrm{~mm} \mathrm{NaCl}, 0.05 \%$ Tween 20) and incubated with alkaline phosphataselabeled antidigoxigenin $\mathrm{F}(\mathrm{ab})_{2}$ fragments (Roche Diagnostics), $1.5 \mathrm{U} / \mathrm{ml}$ in TNT supplemented with $2 \%$ FCS (AbCys) for 30 minutes at room temperature, followed by successive washes with TNT and PBS at room temperature; then sections were placed in 5-bromo4-chloro-3-indolyl phosphate-nitroblue-tetrazolium color substrate solution (Promega) for 10 minutes at room temperature in a dark room. This reaction was stopped by washing for 10 minutes in PBS, and sections were mounted in Faramount medium.

\section{Immunohistochemical Quantification}

The surface areas of the pancreata were assessed using a VIDAS-RT image analysis system (Kontron Elektronik GmbH/Carl Zeiss, Weesp, The Nether- 
lands). Pancreata were encircled by hand, and then the image analyzer made measurements, expressed in pixels, using an objective magnification of $\times 2$. At this magnification, 1 pixel is $0.00011955 \mathrm{~mm}^{2}$. The mean surface areas of the pancreas sections for the various strains were as follows: 1.5 to $3.5 \mathrm{~mm}^{2}$ at 3 days of age, 3 to $5.1 \mathrm{~mm}^{2}$ at 1 week of age, 4.3 to $8.7 \mathrm{~mm}^{2}$ at 2 weeks of age, and 9.4 to $24.4 \mathrm{~mm}^{2}$ at 4 weeks of age. The numbers of positive cells, counted by two investigators, were then expressed per square millimeter of total pancreatic surface area.

\section{Statistical Analyses}

Statistical significance for differences between cell numbers was determined by means of a two-way ANOVA followed by Newman-Keuls post-hoc analysis. The level of significance was set at $p<0.05$. For FasL and TUNEL measurements, a total of 10 mice (1 section/mouse) was analyzed per age-strain combination.

\section{Acknowledgements}

The authors thank Mrs. Cissé for technical assistance and Dr. P. Leenen for providing the MP-23 Ab.

\section{References}

Augstein P, Stephens LA, Allison J, Elefanty AG, Ekberg M, Kay TW, and Harrison LC (1998). Beta-cell apoptosis in an accelerated model of autoimmune diabetes. Mol Med 4:495501.

Bach JF (1994). Insulin-dependent diabetes mellitus as an autoimmune disease. Endocr Rev 15:516-542.

Bacon KB and Harrison JK (2000). Chemokines and their receptors in neurobiology: Perspectives in physiology and homeostasis. J Neuroimmunol 104:92-97.

Bechmann I, Mor G, Nilsen J, Eliza M, Nitsch R, and Naftolin $F$ (1999). FasL (CD95L, Apo1L) is expressed in the normal rat and human brain: Evidence for the existence of an immunological brain barrier. Glia 27:62-74.

Benoist C and Mathis D (1997). Cell death mediators in autoimmune diabetes: No shortage of suspects. Cell 89:1-3.

Boitard C, Villa MC, Becourt C, Gia HP, Huc C, Sempe P, Portier MM, and Bach JF (1992). Peripherin: An islet antigen that is cross-reactive with nonobese diabetic mouse class II gene products. Proc Natl Acad Sci USA 89:172-176.

Bouwens L and De Blay E (1996). Islet morphogenesis and stem cell markers in rat pancreas. J Histochem Cytochem 44:947-951.

Bruck W (1997). The role of macrophages in Wallerian degeneration. Brain Pathol 7:741-752.

Burek MJ and Oppenheim RW (1996). Programmed cell death in the developing nervous system. Brain Pathol 6:427446.

Campani D, Esposito I, Boggi U, Cecchetti D, Menicagli M, De Negri F, Colizzi L, Del Chiaro M, Mosca F, Fornaciari G, and Bevilacqua $\mathrm{G}$ (2001). Bcl-2 expression in pancreas development and pancreatic cancer progression. J Pathol 194:444-450.
Cha S, van Blockland SC, Versnel MA, Homo-Delarche F, Nagashima H, Brayer J, Peck AB, and Humphreys-Beher MG (2001). Abnormal organogenesis in salivary gland development may initiate adult onset of autoimmune exocrinopathy. Exp Clin Immunogenet 18:143-160.

Charré S, Rosmalen JG, Pelegri C, Alves V, Leenen PJ, Drexhage HA, and Homo-Delarche F (2002). Abnormalities in dendritic cell and macrophage accumulation in the pancreas of nonobese diabetic mice during the early neonatal period. Histol Histopathol 17:393-401.

Cuadros MA, Martin C, Coltey P, Almendros A, and Navascues J (1993). First appearance, distribution, and origin of macrophages in the early development of the avian central nervous system. J Comp Neurol 330:113-129.

Dahlen E, Dawe K, Ohlsson L, and Hedlund G (1998). Dendritic cells and macrophages are the first and major producers of TNF-alpha in pancreatic islets in the nonobese diabetic mouse. J Immunol 160:3585-3593.

Dore BA, Grogan WM, Madge GE, and Webb SR (1981). Biphasic development of the postnatal mouse pancreas. Biol Neonate 40:209-217.

Esch TR and Taubman MA (1998). Autoantibodies in salivary hypofunction in the NOD mouse. Ann NY Acad Sci 842:221228.

Fadok VA, Bratton DL, and Henson PM (2001). Phagocyte receptors for apoptotic cells: Recognition, uptake, and consequences. J Clin Invest 108:957-962.

Farlie PG, Dringen R, Rees SM, Kannourakis G, and Bernard O (1995). bcl-2 transgene expression can protect neurons against developmental and induced cell death. Proc Natl Acad Sci USA 92:4397-4401.

Finegood DT, Scaglia L, and Bonner-Weir S (1995). Dynamics of beta-cell mass in the growing rat pancreas: Estimation with a simple mathematical model. Diabetes 44:249-256.

Gilon P and Henquin JC (2001). Mechanisms and physiological significance of the cholinergic control of pancreatic beta-cell function. Endocr Rev 22:565-604.

Granville DJ, Carthy CM, Hunt DW, and McManus BM (1998). Apoptosis: Molecular aspects of cell death and disease. Lab Invest 78:893-913.

Greeley SA, Katsumata M, Yu L, Eisenbarth GS, Moore DJ, Goodarzi H, Barker CF, Naji A, and Noorchashm H (2002). Elimination of maternally transmitted autoantibodies prevents diabetes in nonobese diabetic mice. Nat Med 8:399402.

Greenlund LJ, Korsmeyer SJ, and Johnson EM Jr (1995). Role of BCL-2 in the survival and function of developing and mature sympathetic neurons. Neuron 15:649-661.

Griffith TS and Ferguson TA (1997). The role of FasL-induced apoptosis in immune privilege. Immunol Today 18:240-244.

Haanen C and Vermes I (1996). Apoptosis: Programmed cell death in fetal development. Eur J Obstet Gynecol Reprod Biol 64:129-133.

Hanke J (2000). Apoptosis and occurrence of Bcl-2, Bak, Bax, Fas and FasL in the developing and adult rat endocrine pancreas. Anat Embryol (Berl) 202:303-312.

Hesselgesser J and Horuk R (1999). Chemokine and chemokine receptor expression in the central nervous system. J Neurovirol 5:13-26. 
Homo-Delarche $F$ (2001). Is pancreas development abnormal in the non-obese diabetic mouse, a spontaneous model of type I diabetes? Braz J Med Biol Res 34:437-447.

Homo-Delarche F (1997). Beta-cell behaviour during the prediabetic stage. Part II. Non-insulin-dependent and insulindependent diabetes mellitus. Diabetes Metab 23:473-505.

Honjin $H$ (1956). The innervation of the pancreas of the mouse, with special reference to the structure of the peripheral extension of the vegetative nervous system. J Comparative Neurol 104:331-371.

Hugues S, Mougneau E, Ferlin W, Jeske D, Hofman P, Homann D, Beaudoin L, Schrike C, Von Herrath M, Lehuen A, and Glaichenhaus N (2002). Tolerance to islet antigens and prevention from diabetes induced by limited apoptosis of pancreatic beta cells. Immunity 16:169-181.

Jansen A, Homo-Delarche F, Hooijkaas H, Leenen PJ, Dardenne M, and Drexhage HA (1994). Immunohistochemical characterization of monocytes-macrophages and dendritic cells involved in the initiation of the insulitis and beta-cell destruction in NOD mice. Diabetes 43:667-675.

Kerr JF, Wyllie AH, and Currie AR (1972). Apoptosis: A basic biological phenomenon with wide-ranging implications in tissue kinetics. Br J Cancer 26:239-257.

Kieseier BC, Krivacic K, Jung S, Pischel H, Toyka KV, Ransohoff RM, and Hartung HP (2000). Sequential expression of chemokines in experimental autoimmune neuritis. J Neuroimmunol 110:121-129.

Kobayashi H, Doi R, Hosotany R, Myamoto Y, Koshiba T, Fujimoto K, Ida J, Tsuji S, Nakajima H, Kawagachi M, Shiota $\mathrm{K}$, and Imamura M (2000). Immunohistochemical analysis of apoptosis-related proteins in human embryonic and fetal pancreatic tissues. Int J Pancreatol 27:113-122.

Kuhlmann T, Bitsch A, Stadelmann C, Siebert H, and Bruck W (2001). Macrophages are eliminated from the injured peripheral nerve via local apoptosis and circulation to regional lymph nodes and the spleen. J Neurosci 21:34013408.

Kurrer MO, Pakala SV, Hanson HL, and Katz JD (1997). Beta cell apoptosis in T cell-mediated autoimmune diabetes. Proc Natl Acad Sci USA 94:213-218.

Kusakabe T, Matsuda H, Kawakami T, Syoui N, Kurihara K, Tsukuda M, and Takenaka T (1997). Distribution of neuropeptide-containing nerve fibers in the human submandibular gland, with special reference to the difference between serous and mucous acini. Cell Tissue Res 288:25-31.

Lang RA and Bishop JM (1993). Macrophages are required for cell death and tissue remodeling in the developing mouse eye. Cell 74:453-462.

Leenen PJ, de Bruijn MF, Voerman JS, Campbell PA, and van Ewijk W (1994). Markers of mouse macrophage development detected by monoclonal antibodies. J Immunol Methods 174:5-19.

Legg PG (1968). Fluorescence studies on neural structures and endocrine cells in the pancreas of the cat. Z Zellforsch Mikrosk Anat 88:487-495.

Lety MA, Coulaud J, Bens M, Dardenne M, and HomoDelarche $F$ (1992). Enhanced metabolism of arachidonic acid by macrophages from nonobese diabetic (NOD) mice. Clin Immunol Immunopathol 64:188-196.
Luan JJ, Monteiro RC, Sautes C, Fluteau G, Eloy L, Fridman WH, Bach JF, and Garchon HJ (1996). Defective Fc gamma RII gene expression in macrophages of NOD mice: Genetic linkage with up-regulation of $\operatorname{lgG} 1$ and $\lg G 2 \mathrm{~b}$ in serum. J Immunol 157:4707-4716.

Marrack P, Kappler J, and Kotzin BL (2001). Autoimmune disease: Why and where it occurs. Nat Med 7:899-905.

Martin-Villalba A, Herr I, Jeremias I, Hahne M, Brandt R, Vogel J, Schenkel J, Herdegen T, and Debatin KM (1999). CD95 ligand (Fas-L/APO-1L) and tumor necrosis factorrelated apoptosis-inducing ligand mediate ischemia-induced apoptosis in neurons. J Neurosci 19:3809-3817.

Mevorach D, Zhou JL, Song X, and Elkon KB (1998). Systemic exposure to irradiated apoptotic cells induces autoantibody production. J Exp Med 188:387-392.

Miyamoto Y, Hosotani R, Wada M, Lee JU, Koshiba T, Fujimoto K, Tsuji S, Nakajima S, Doi R, Kato M, Shimada Y, and Imamura M (1999). Immunohistochemical analysis of $\mathrm{Bcl}-2$, Bax, Bcl-X, and $\mathrm{Mcl}-1$ expression in pancreatic cancers. Oncology 56:73-82.

Moujahid A, Navascues J, Marin-Teva JL, and Cuadros MA (1996). Macrophages during avian optic nerve development: Relationship to cell death and differentiation into microglia. Anat Embryol (Berl) 193:131-144.

O'Brien BA, Harmon BV, Cameron DP, and Allan DJ (1997). Apoptosis is the mode of beta-cell death responsible for the development of IDDM in the nonobese diabetic (NOD) mouse. Diabetes 46:750-757.

O'Brien BA, Huang Y, Geng X, Dutz JP, and Finegood DT (2002). Phagocytosis of apoptotic cells by macrophages from NOD mice is reduced. Diabetes 51:2481-2488.

Park C, Sakamaki K, Tachibana O, Yamashima T, Yamashita $\mathrm{J}$, and Yonehara S (1998). Expression of fas antigen in the normal mouse brain. Biochem Biophys Res Commun 252: 623-628.

Pelegri C, Rosmalen JG, Durant S, Throsby M, Alves V, Coulaud J, Esling A, Pleau JM, Drexhage HA, and HomoDelarche $F$ (2001). Islet endocrine-cell behavior from birth onward in mice with the nonobese diabetic genetic background. Mol Med 7:311-319.

Perry VH and Brown MC (1992). Macrophages and nerve regeneration. Curr Opin Neurobiol 2:679-682.

Persson-Sjogren S (2001). Neuroinsular complex type I: Morphology and frequency in lean and genetically obese mice. Pancreas 23:40-48.

Petrik J, Arany E, McDonald TJ, and Hill DJ (1998). Apoptosis in the pancreatic islet cells of the neonatal rat is associated with a reduced expression of insulin-like growth factor II that may act as a survival factor. Endocrinology 139:2994-3004.

Piganelli JD, Martin T, and Haskins K (1998). Splenic macrophages from the NOD mouse are defective in the ability to present antigen. Diabetes 47:1212-1218.

Platt N, da Silva RP, and Gordon S (1998). Recognizing death: The phagocytosis of apoptotic cells. Trends Cell Biol 8:365-372.

Portier MM, Escurat M, Landon F, Djabali K, and Bousquet O (1993). Peripherin and neurofilaments: Expression and role during neural development. C R Acad Sci Paris 316:11331140 . 
Prochazka M, Gaskins HR, Shultz LD, and Leiter EH (1992). The nonobese diabetic scid mouse: Model for spontaneous thymomagenesis associated with immunodeficiency. Proc Natl Acad Sci USA 89:3290-3294.

Radosevic K, Casteels KM, Mathieu C, Van Ewijk W, Drexhage HA, and Leenen PJ (1999). Splenic dendritic cells from the non-obese diabetic mouse induce a prolonged proliferation of syngeneic T cells: A role for an impaired apoptosis of NOD T cells? J Autoimmun 13:373-382.

Raoul C, Henderson CE, and Pettmann B (1999). Programmed cell death of embryonic motoneurons triggered through the Fas death receptor. J Cell Biol 147:1049-1062.

Rosen A and Casciola-Rosen L (2001). Clearing the way to mechanisms of autoimmunity. Nat Med 7:664-665.

Rosmalen JG, Homo-Delarche F, Durant S, Kap M, Leenen $\mathrm{PJ}$, and Drexhage HA (2000a). Islet abnormalities associated with an early influx of dendritic cells and macrophages in NOD and NOD scid mice. Lab Invest 80:769-777.

Rosmalen JG, Leenen PJ, Pelegri C, Drexhage HA, and Homo-Delarche $F$ (2002). Islet abnormalities in the pathogenesis of autoimmune diabetes. Trends Endocrinol Metab 13: 209-214.

Rosmalen JG, Martin T, Dobbs C, Voerman JS, Drexhage HA, Haskins K, and Leenen PJ (2000b). Subsets of macrophages and dendritic cells in nonobese diabetic mouse pancreatic inflammatory infiltrates: Correlation with the development of diabetes. Lab Invest 80:23-30.

Sabelko-Downes KA and Russell JH (2000). The role of fas ligand in vivo as a cause and regulator of pathogenesis. Curr Opin Immunol 12:330-335.

Saikumar P, Dong Z, Mikhailov V, Denton M, Weinberg JM, and Venkatachalam MA (1999). Apoptosis: Definition, mechanisms, and relevance to disease. Am J Med 107:489-506.

Sakata K, Sakata A, Kong L, Dang H, and Talal N (1998). Role of Fas/FasL interaction in physiology and pathology: The good and the bad. Clin Immunol Immunopathol 87:1-7.

Saravia-Fernandez F, Faveeuw C, Blasquez-Bulant C, Tappaz M, Throsby M, Pelletier G, Vaudry H, Dardenne M, and Homo-Delarche $F$ (1996). Localization of gammaaminobutyric acid and glutamic acid decarboxylase in the pancreas of the nonobese diabetic mouse. Endocrinology 137:3497-3506.

Scaglia L, Cahill CJ, Finegood DT, and Bonner-Weir S (1997). Apoptosis participates in the remodeling of the endocrine pancreas in the neonatal rat. Endocrinology 138:1736-1741.

Serizawa Y, Kobayashi S, and Fujita T (1979). Neuro-insular complex type I in the mouse: Re-evaluation of the pancreatic islet as a modified ganglion. Arch Histol Jpn 42:389-394.

Serreze DV, Gaskins HR, and Leiter EH (1993). Defects in the differentiation and function of antigen presenting cells in NOD/Lt mice. J Immunol 150:2534-2543.

Sharma K, Wang RX, Zhang LY, Yin DL, Luo XY, Solomon JC, Jiang RF, Markos K, Davidson W, Scott DW, and Shi YF (2000). Death the Fas way: Regulation and pathophysiology of CD95 and its ligand. Pharmacol Ther 88:333-347.

Siegel RM, Chan FK, Chun HJ, and Lenardo MJ (2000). The multifaceted role of Fas signaling in immune cell homeostasis and autoimmunity. Nat Immunol 1:469-474.
Signore A, Annovazzi A, Gradini R, Liddi R, and Ruberti G (1998). Fas and Fas ligand-mediated apoptosis and its role in autoimmune diabetes. Diabetes Metab Rev 14:197-206.

Signore A, Annovazzi A, Procaccini E, Beales PE, Spencer J, Testi R, and Ruberti G (1997). CD95 and CD95-ligand expression in endocrine pancreas of NOD, NOR and BALB/c mice. Diabetologia 40:1476-1479.

Sorenson RL, Garry DG, and Brelje TC (1991). Structural and functional considerations of GABA in islets of Langerhans: Beta-cells and nerves. Diabetes 40:1365-1374.

Sunami E, Kanazawa H, Hashizume H, Takeda M, Hatakeyama K, and Ushiki T (2001). Morphological characteristics of Schwann cells in the islets of Langerhans of the murine pancreas. Arch Histol Cytol 64:191-201.

Teitelman G, Guz Y, Ivkovic S, and Ehrlich M (1998). Islet injury induces neurotrophin expression in pancreatic cells and reactive gliosis of peri-islet Schwann cells. J Neurobiol 34:304-318.

Thomas HE, Darwiche R, Corbett JA, and Kay TW (1999). Evidence that beta cell death in the nonobese diabetic mouse is Fas independent. J Immunol 163:1562-1569.

Tisch R, Yang XD, Singer SM, Liblau RS, Fugger L, and McDevitt HO (1993). Immune response to glutamic acid decarboxylase correlates with insulitis in non-obese diabetic mice. Nature 366:72-75.

Trudeau JD, Dutz JP, Arany E, Hill DJ, Fieldus WE, and Finegood DT (2000). Neonatal beta-cell apoptosis: A trigger for autoimmune diabetes? Diabetes 49:1-7.

van Blokland SC, van Helden-Meeuwsen CG, Wierenga-Wolf $A F$, Drexhage HA, Hooijkaas $H$, van de Merwe JP, and Versnel MA (2000). Two different types of sialoadenitis in the NOD- and MRL/Ipr mouse models for Sjögren's syndrome: A differential role for dendritic cells in the initiation of sialoadenitis? Lab Invest 80:575-585.

Vaux DL and Korsmeyer SJ (1999). Cell death in development. Cell 96:245-254.

Wada M, Doi R, Hosotani R, Lee JU, Fujimoto K, Koshiba T, Miyamoto Y, Fukuoka S, and Imamura M (1997). Expression of $\mathrm{Bcl}-2$ and PCNA in duct cells after pancreatic duct ligation in rats. Pancreas 15:176-182.

Wang X, Ellison JA, Siren AL, Lysko PG, Yue TL, Barone FC, Shatzman A, and Feuerstein GZ (1998). Prolonged expression of interferon-inducible protein-10 in ischemic cortex after permanent occlusion of the middle cerebral artery in rat. J Neurochem 71:1194-1204.

Winer S, Astsaturov I, Cheung R, Gunaratnam L, Kubiak V, Cortez MA, Moscarello M, O'Connor PW, McKerlie C, Becker DJ, and Dosch HM (2001a). Type I diabetes and multiple sclerosis patients target islet plus central nervous system autoantigens: Nonimmunized nonobese diabetic mice can develop autoimmune encephalitis. J Immunol 166:2831-2841.

Winer S, Astsaturov I, Cheung RK, Schrade K, Gunaratnam L, Wood DD, Moscarello MA, O'Connor P, McKerlie C, Becker DJ, and Dosch HM (2001b). T cells of multiple sclerosis patients target a common environmental peptide that causes encephalitis in mice. J Immunol 166:4751-4756.

Wohlleben G, Ibrahim SM, Schmidt J, Toyka KV, Hartung HP, and Gold R (2000). Regulation of Fas and FasL expression on rat Schwann cells. Glia 30:373-381. 